\title{
Beyond Emptiness: A Critical Review
}

HALLA KIM

Sogang University, Korea/University of Nebraska at Omaha, USA (hallakim@unomaha.edu)

In his recent book, Jae-Seong Lee argues that not only Eastern thoughts but also Western philosophy lead us to transcend our ordinary, binary, reflexive thought and become one with the truth, namely, Emptiness, or the true self. But this aspect has not been thoroughly considered in Western metaphysics. After considering Heidegger's failure to get to the bottom of transcendence through his "Dasein," Lee looks to the French postmodern ethicists, in particular, Levinas, in this regard. Just like the Mahayana Buddhist philosopher Nägärinna did almost two thousand years earlier, Lee suggests that Levinas too may have hit upon the insight that genuine subjectivity can be reached through an openness to the Other as the wholly exterior. Throughout the entire book, Jae-Seong Lee shows a strong interest in postmodern ethics, Daoism, Buddhism, theology, and literature, but in the end, he concludes that Buddhist philosophy, with its focus on Emptiness, would be the best approach to a merging of Eastern and Western Ways of thinking in our search for the ultimate and absolute. Finally, Lee suggests that the general philosophical theory he introduces and develops actually works for literary works including the Book of Job, Count Dracula and Frankenstein.

Keywords: Postmodern Ethics; Daoism; Buddhism; Levinas; Derrid; Deleuze; the Other; Emptiness (Śünyatä); Buddha-nature; Seon (Zen/Chan); Gongan (koan); Nāgārjuna; Heidegger; Dasein; seated meditation

JAE-SEONG LEE, Postmodern Ethics, Emptiness, and Literature: Encounters between East and West, Lanham: Lexington Books, 2015. xxvii, 261 pages

This interesting and pioneering work by Jae-Seong Lee shows a strong interest in postmodern ethics, Daoism, Buddhism, theology, and literature. Among the major views in postmodern ethics, the ethical philosophy of Emmanuel Levinas is given a prominent attention. ${ }^{1}$ In particular, Levinas' view of the Other is carefully introduced, analyzed and assessed. More importantly, a systematic comparison with the Buddhist notion of Emptiness is attempted throughout the book.

The whole book is divided into two halves, the first dealing with a general philosophical theory, following the Foreword and Introduction, and the second its application. Lee is of the view that the general theory he introduces and develops actually works for literary reading. In other words, various literary texts can be read in view of their potential to elevate the soul to the level of the infinity of the Other (239) in the process of a unique integration of the Western thought into the Eastern thought. In Chapter I, it is repeatedly pointed out that postmodern/structuralist ethics came to share the same kind of intrinsic nature as Buddhism. Levinas is portrayed as presenting the Other in its most acute form and as being closest to the Buddhist philosophy of

Journal of World Philosophies 2 (Summer 2017): 188-194

Copyright (C) 2017 Halla Kim.

e-ISSN: 2474-1795 • http://scholarworks.iu.edu/iupjournals/index.php/jwp• doi: 10.2979/jourworlphil.2.1.16 
perfect Emptiness. Chapter II presents the major view in postmodern ethics with a focus on Levinas. All these ethicists, Lee argues, pursue genuine transcendence, which truly destroys totality, and it is emphatically suggested that Levinas' view of the infinity of the Other is substantially closest to the notion of Emptiness in Seon (the Korean word for Zen/Chan) Buddhism. Chapter III is a continuation of the same theme but delves in Levinas' conception of infinity and its repercussions in the Buddhist conception of Emptiness. In Chapter IV Buddhist and Daoist philosophy are presented as providing the ground of thoughts and wisdom of infinity. Gongan (the Korean word for Koan, the puzzle questions for meditation) is also introduced. Just as Gongan leads to awakening, the irony or self-contradiction of a literary text as the object of deconstruction can lead to genuine transcendence of the infinite. In Chapter V, Lee presents his reading of religious texts, especially the Book of Job. The ultimate object of the text is God as the absolute Other or Emptiness. In Chapter VI, Lee analyzes the Gothic novel Count Dracula and presents Dracula as the emblem of the unknown Other that engenders in the reader's mind the surplus of horrifying evil power. Chapter VII concerns the excess of terror mood in Frankenstein, and offers a narrative on the basis of the structure of the self-Other relation, which corresponds to a distinct mirroring mechanism of the protagonist-monster relationship. In a nutshell, Lee claims that we need the Buddhist philosophy of Emptiness, which is not just another route to the heterogeneous realm of reality, but a superior route to the Other.

\section{3}

From the outset, Lee diligently and methodically surveys the major views in postmodern ethics against the background of traditional Western philosophy, i.e., modern metaphysics of presence. This involves an erudite and informed exposition of the main French postmodern views of Levinas, Derrida, Lyotard, Deleuze and Nancy, as well as their German predecessors such as Kant, Hegel, Husserl and Heidegger.

Lee also points out that Western philosophers have been prone to misunderstanding Eastern thoughts, for example, in Hegel and Nietzsche $(6,103)$. Western philosophy, despite being an ontology, has been in search of the Other. In his search for reality, Kant suggests that transcendental apperception is distinct from the empirical or inner apperception. Lee explains that the Kantian transcendental apperception here is beyond time and space.

Heidegger speaks of Dasein, “man's being as a manifestation of Being” (81). But he was not able to get to the bottom of transcendence, Lee suggests. Had the post-Heideggerian postmodern views made the same mistake? Lee emphatically suggests that this scenario is unlikely. It is surprising to learn that Levinas, Lacan, Deleuze and Nancy, just as the Mahayana Buddhist philosopher Nāgārjuna did almost two thousand years earlier, acknowledge and explain in their own ways that genuine subjectivity lies beyond empirical subjectivity. Genuine subjectivity is the pure self that is void of spoken or written language (72). In particular, the ethical turn in the 1980s and 1990s ushered in by Levinas and Derrida made possible the openness to the Other as the wholly exterior (17). After this development, a new route is open to non-representational transcendence that is beyond the supplementarity or play of presence and absence. This is prominently observed in the ethical philosophy of Levinas.

Following Levinas—but critically, not blindly_Derrida opposes the traditional sense of transcendence, the sense of the transcendental signified, the first cause, etc. (16) — but ends up embracing the openness to the Other (or transcendence without representation). Derrida deconstructs the tradition of Western philosophy and shares the common ground with Buddhism. There are similarities between Derrida's notion of deconstruction and the Buddhist Emptiness as we will discuss it shortly. Thus, there is genuine human transcendence for Derrida. The latter suggests that the goal of his deconstruction is to reach the Other (39), which is "neither a being nor a concept of the absolute existence or identity" (37). But this way of thinking is

Journal of World Philosophies 2 (Summer 2017): 188-194

Copyright (C) 2017 Halla Kim.

e-ISSN: 2474-1795 • http://scholarworks.iu.edu/iupjournals/index.php/jwp• doi: 10.2979/jourworlphil.2.1.16 
clearly different from that of Levinas. For the latter holds that the fundamental human relation of the self with the Other is non-ontological (in a genuinely transcendent language) based on transcendent human condition (39-40). But deconstruction cannot provide fundamental ethics in dealing with the core of humanity that lies outside the realm of presence and phenomenality (40). Thus, Derrida, just like Heidegger earlier, falls short of getting to the bottom of the matter as far as transcendence is concerned. Most importantly, Derrida remains a skeptic and shows no real affirmation of exteriority of the human self (43).

\section{4}

As pointed out earlier, Emptiness is the Buddhist concept that occupies the central place in Lee's exposition of Buddhism. What is Emptiness? Lee concedes that Emptiness must be an essentially perplexing issue for Western philosophers to comprehend because it commands at least some pre-reflective spiritual realization of it above intellectual apprehension.

The concept of Emptiness in Nāgārjuna has to do with dependent co-origination (Pratityasamutpäda): every dharma (thing) is dependently originated. Nāgārjuna equates Emptiness with dependent origination in Mülamadhyamakakārikè 24:18. Shakyamuni Buddha's teaching includes Emptiness but it was Nāgārjuna who made it a cornerstone of his philosophy.

The notion of dependent co-origination destroys the structure of binary operation that comprises all phenomena. Relying on Derrida, Lee explains that binary operation is a structure of the mind refined by itself to see only what it chooses to see as it posits the value of the one of the polar opposites over that of the other. A meaning takes place "as this production of inequality happens" (12). The logic of binary operation "yields meaning and values, as one of the two terms is seen to dominate and control the other" (10). Emptiness then deconstructs the meaning and value of discrete things for us.

After initially characterizing Emptiness negatively, Lee also presents the notion more positively. It is the space in which "the self is ruptured but the person is on the way to awakening" (12). It is the pre-conceptual and non-dualistic, that is, pure and original, nature of humanity (ibid.) accessible only by direct experience, e.g., seated meditation. It is the wholeness, i.e., the ultimate reality of the whole universe (113). Furthermore, it is not passive but active as it produces the whole phenomenon. While detached from ordinary experience, Emptiness is the source of the empirical dimension (52). Emptiness is the fullness of infinite ethical interrelations that disseminates beyond phenomenal events, giving birth to phenomena (113). To sum up, Emptiness is not only transcendence but also immanence, i.e., "Emptiness is form and form is Emptiness" $(111,112,113$, originally from the Heart Sutra.)

While there is no denying that Emptiness $(10,12)$ is a central notion in Buddhism, this Buddhist Emptiness (11) is not identical with Dao (ibid.) in Daoism. Once again, in a bold claim, Lee suggests that "[D]ao of [D]aoism is the term we can replace even with Emptiness" (122). True, Deleuze and Guattari obviously link their idea of the pure desire with Dao, using actually the term "Tao" (i.e., Dao). Since Dao also connotes fullness of being as well as its absence, Lee goes on to hold that Dao can be identified with Emptiness. This is a tall claim that needs to be substantiated in detail. It is widely acknowledged that there is a remarkable similarity between Indian Buddhism and Chinese Daoism. Indeed, Daoist ideas were first used to explain Buddhist ideas when Buddhism first arrived in China from India. This is sometimes called “Geyi” (格義) Buddhism but soon it was made obvious that this method had serious shortcomings and led to gross misunderstanding. Buddhism is not a native Chinese thought and Dao is not Emptiness in this Buddhist sense.

Now, at several critical junctures, Lee goes on to identify preconceptual self (113) as expressing the Buddha nature (Tathagatagarbha). Lee is not afraid of asserting that the Buddha nature, one of the most pivotal

Journal of World Philosophies 2 (Summer 2017): 188-194

Copyright (C) 2017 Halla Kim.

e-ISSN: 2474-1795 • http://scholarworks.iu.edu/iupjournals/index.php/jwp• doi: 10.2979/jourworlphil.2.1.16 
concepts in East Asian Buddhism, is none other than Śmnyatā or Emptiness, outside the ontological self, whose primary capacity is perceiving, understanding, or conceptualizing (110). For the real self is fully awakened to Emptiness, which is the ultimate reality. It is a short step from here to hold then that the Buddhist notion of the real self, the Buddha nature, is also the same as Emptiness (112). Again, this identification is precarious because the introduction of the Buddha nature in Mahayana Buddhism has always raised the suspicion that Buddhism, in this form, perhaps gave up on the notion of anattā (anätman), the non-self. However, Emptiness is the term that does not raise such a specter. It must be pointed out that most scholars trace the origin of the doctrine of the real self to the Nirvana Sutra (Mahäparinirvanna Sütra) as the locus classicus of this doctrine. Since the Nirvana Sutra derives some of its leading inspiration from teachings of the Tathaggatagarbha Sütra, we can see that the doctrine of the real self goes hand in hand with the Buddha nature. Finally, Lee's identification of Emptiness with thusness (tathata) is also equally problematic.

\section{5}

Lee's case for the Korean contribution to the understanding of Buddhism and Emptiness is presented with his discussion of the Korean monk Jinul (Chinul) (1158-1210) and his Seon Buddhism. In this form of Buddhism, there is a great emphasis on practices-mainly seated-meditation with gongan (124). In awakening to the reality, the ordinary self is lost in this form of Seon Buddhism in favor of the non-dual subjectivity. In seated meditation, Zen Buddhist monks come to use "live words, not dead words" (12). Lee's interesting contention here is that literary texts work just like gongan (127). Ganhwaseon (the meditation technique by way of Hwadu, which is the keywords of gongan) is also introduced (130) but Lee needs to explain this concept in more detail. "Tracing back the radiance" is a central term in Zen Buddhism especially in Jinul, even though the concept itself can be traced back to the Chinese monk Linji in his The Record of Linji. This notion means ceasing to have the images of objects outside of the mind and entering the mind itself. It is a process by which the mind severs its connection to experience and realizes that the essence of itself is Emptiness (103). Despite Lee's effort to bring out the Korean contribution to Zen literature, Lee ends up barely scratching the surface of Korean Seon Buddhist thought. Other than a single strand of Jinul's thought, there is no clear respect or area in which the Korean contribution makes a crucial difference to Lee's overall argument.

If I understand Lee's Buddhism correctly, his Buddhism is a philosophy of subjectivity (in its elevated sense) at its heart. Samädhi (meditational absorption) heightens our awareness of the Buddha beyond all phenomena. But this Buddha is found nowhere except in each of us the subject. Lee contends that this awareness is also the ultimate goal of literature and the arts, despite the difference between religion and literary reading. Lee's Buddhism then is about obtaining this awareness. Lee also suggests that consciousness and time are the most vital components of being (132). This suggests that Buddhism essentially includes the thesis of idealism. In this respect, the Buddhist notion of time is the most fundamental. Time, like phenomena and our ego, is empty and not an entity. Nāgārjuna once suggested that there is no substance of time (137). But it is a short step from here to paint an anthropocentric or speciesist picture of Buddhism. As Lee puts it,

the dimension of the Middle Path, rhizome, the virtual, or "thing-in-itself" is no doubt the ethical dimension out of binary opposition and totality; in it, no reflection, no giving and taking rule is possible.

Journal of World Philosophies 2 (Summer 2017): 188-194

Copyright (C) 2017 Halla Kim.

e-ISSN: 2474-1795 • http://scholarworks.iu.edu/iupjournals/index.php/jwp• doi: 10.2979/jourworlphil.2.1.16 
In that dimension, only a nonreciprocal relation is possible, and this relation is perfectly ethical because it means one is totally for the others (56).

If humanity should be considered merely as one of the other elements of the world, there would be no fundamental, that is, nonontological, difference between human life and animal life. To come straight to the point, one can add that there would be no fundamental difference even between the human world and the world of cybernetics (45).

On this concept of Buddhism, Emptiness is not an ontological category. The realization of Emptiness does not seem to change anything. It is rather about one's perspective.

It is now clear that Lee hopes to defend this Buddhist insight within the broad framework of postmodern ethics. To quote Lee again,

[b]oth Eastern and Western philosophies lead us to transcend our reflexive thought and become one with the ultimate-namely infinity or Emptiness, or the true self, which has not been considered in the Western metaphysics (xxii).

In this picture, it is only natural to suggest that Buddhist philosophy would be the best approach to a merging of Eastern and Western Ways of thinking (101). But Lee also emphasizes that Buddhist Emptiness would not be "different from what Levinas means by God, the absolute Other-the whole exterior of the self" (112). In a nutshell, Lee sums his effort up by suggesting that "this study will be an attempt to connect Levinas' ethical insight into the Other with the Emptiness in Zen Buddhist philosophy. Levinasian ethics and Seon Buddhism can be interrelated and united with each other" (100). In this respect, Levinas is more compatible with Zen Buddhism than any other postmodern thinkers (41). Although Levinas' ethical thought is not on such a vast scale of description as Buddhism's, it directs us to essentially the same point (141). Lee says it is the true Emptiness in Buddhism that is the wholly Other in Levinas (112). What Levinas means by "the pure I" is remarkably similar to the Buddha nature as the pure Emptiness (ibid.). Therefore, Lee concludes that Levinas' way of viewing interrelatedness essentially corresponds to Buddhism (115).

\section{7}

But he also warns us against the simple-minded identity between Levinas' view and Buddhism. Levinas' real I is only "incessant awakening" (113). The pure I in Levinas is only similar but not identical to the Buddha nature (112). Furthermore, Levinas' ethical relation is limited to self-Other relation but Buddhist Emptiness is true of all things whatsoever. While Levinas' transcendence is ethical, Buddhist Emptiness is cosmic and universal (115). In Buddhism, the ultimate awakening takes place in the depth of subjectivity, i.e., by means of "the real self," or the real subject, and not by means of the Other (101). In other words, Levinas fails to present the most fundamental dimension of humanness and phenomena. This partly explain why Levinas could not have come up with the fundamental insight that form is Emptiness and Emptiness is form. Finally, Levinas does not consider the way in which we grow ethically. Mabayana Buddhism "aims to enable individuals to attain a psychological, and ultimately spiritual, awakening, and also contributes to helping as many other people in the world as possible to attain enlightenment for themselves" (66).

Lee then engages in a sustained rumination on the notion of self or I. The real self in Buddhism goes beyond all empirical, contingent minds with all their conceptual distinctions and intellectual discriminations. Lee also speaks of the Kantian transcendental apperception (103). But this is not the same as the real I, which is the noumenal I in Kant. Levinas does not lead us to this point of ultimacy of the real I or no self (102). First,

Journal of World Philosophies 2 (Summer 2017): 188-194

Copyright (C) 2017 Halla Kim.

e-ISSN: 2474-1795 • http://scholarworks.iu.edu/iupjournals/index.php/jwp• doi: 10.2979/jourworlphil.2.1.16 
the true I that Levinas calls the pure I is the non-empirical self that is just for the Other without returning to itself. But pure I is not the same as the Other. Here the self is the substitution of or hostage to the Other. As Lee puts it, the non-empirical dimension of Emptiness is "the exteriority, the dimension where the self has an ethical relation with the Other, as Levinas illuminates" (118). However, Emptiness is the dimension of infinity that really stops our thinking, and this is where Buddhism would contribute a great deal.

Now, even though a literary text is not a human Other, it is able to motivate the reader to activate their "fundamental" desire for the Other. In the second half of the work, Lee contends "that the reader, while reading, is in search of the ethical I, which Levinas characterizes with openness toward the Other" (52). The profound desire for the Other here is comparable to Levinas' "metaphysical" desire. Lee's suggestion thus is that a theory of ethical reading of the text should take a positive attitude toward the Other (79). This implies that we have to read the literary texts only for the purpose of ethics or at least with a focus on it. Lee sometimes goes so far as claiming that in the light of Zen Buddhism, the ultimate goal of literary reading is to reach the non-dual transcendence of the mind-the Buddha nature.

For example, in Chapter V, the Book of Job, an ancient Jewish text, is portrayed as leading us to God as the absolute Other (149). Here the readers are drawn to God as the ultimate reality, but not the traditional logocentric concept. And this reality is identified with Emptiness of Mahayana Buddhism. The Book of Job then epitomizes the reader's search for the ultimate source of life's irony that good people suffer. And like Job they come to unconditionally accept the whole heterogeneous Other.

Also, in the novel Count Dracula, the excess of the Gothic mood (i.e., horror mood) leads to the dimension of the infinity beyond duality and discursiveness (239). Gothic excess is now presented as the trace of the Other here. But this is only a symptom of our inclination to enjoy mysteries or ghost stories, which drives us out of the domain of normality and rationality in binary operations into the realm of transcendence beyond any sensation and conceptual discernment. Count Dracula is thus an epitome of the unknown Other. Dracula gives rise to the excess of frightening evil power, which then leads not only to the glimpse of the infinity of the Other but also to the real self. We can see that horror is the ruling principle of the sublime. And the feeling of sublime plays a big role in having the Other as the exterior of the self in view, and this is none other than the dimension of ethical consciousness toward and for the absolutely heterogenous Other. The feeling of sublime as the experience of suffering, horror, and pleasure is the greatest power in breaking the limitation of the finite subjectivity (238). This feeling then enables the reader to enjoy the thrill and finally liberation from binary oppositions.

Frankenstein continues the same theme with its portrayal of a monster as the trace of the Other that lies exterior to the self (207). Ironically it is also this Other that emerges as the real self. Victor Frankenstein has a genuine desire for the Other that is only seen in the monster (208). This desire has no particular human being or phenomenon as its object (214). Our fear of the Other is a reflection of, or rather our fundamental desire, for the Other (209). The core of humanity is found not in finite self but in the transcendent Other. Since this Other is identified with the Mabayanan Emptiness by Lee, the ultimate objective of the reading of Gothic novel is to attain Buddha nature. It is now obvious that Levinasian thought and Seon Buddhism should be united for the future advancement of ethical philosophy and literary theory $(80){ }^{2}$

Journal of World Philosophies 2 (Summer 2017): 188-194

Copyright (c) 2017 Halla Kim.

e-ISSN: 2474-1795 • http://scholarworks.iu.edu/iupjournals/index.php/jwp• doi: 10.2979/jourworlphil.2.1.16 


\section{9}

As should be clear from our discussion so far, we can find much that is of interest in this well-executed monograph. Its arguments are of a high standard and its content is rich. It is a fitting contribution to an interdisciplinary perspective on philosophy, religion and literature. Despite some of the problems I pointed out, this books explores a fascinating topic on a fundamentally sound project and I recommend it to whoever is interested in comparative philosophy, Asian philosophy, East-West dialogues as well as literary critics. I also look forward to a sequel to this book in the future. ${ }^{3}$

Halla Kim is professor of philosophy at Sogang University, Korea and University of Nebraska at Omaha, USA. His teaching and researching interests include German Idealism and East Asian Philosophy. Currently he is pursuing a project on the problem of origin in world philosophies.

$1 \quad$ All page references will be to the book under review. For the Romanization of Korean I employ the Revised Romanization method and for the Romanization of Chinese I use Pinyin.

2 For another attempt in this direction, see, e.g., ed. Leah Kalmanson, Frank Garrett and Sarah Mattice, Levinas and Asian Thought (Pittsburgh: Duquesne University Press, 2013).

3 Thanks go to two anonymous referees as well as the editor for comments on this review.

Journal of World Philosophies 2 (Summer 2017): 188-194 